\title{
Legal Understanding Regarding The Hazards of Drugs in The Framework of Community Development
}

\begin{tabular}{|c|c|}
\hline \multicolumn{2}{|c|}{$\begin{array}{c}\text { Sami'an } \\
\text { Faculty of Law, Universitas Pekalongan, Pekalongan, Indonesia }\end{array}$} \\
\hline Info Artikel & Abstract \\
\hline \multirow[t]{2}{*}{$\begin{array}{l}\text { Keywords: } \\
\text { Understanding of The Law; } \\
\text { Community Development; } \\
\text { Drug Misuse. }\end{array}$} & $\begin{array}{l}\text { Drug misusse is a danger that is very alarming, because } \\
\text { narcotics can damage the individual users, either physically or } \\
\text { mentally. Misue and trafficking of narcotics illegally very } \\
\text { detrimental to individuals and the wider community, } \\
\text { particularly the younger generation, can even pose a greater } \\
\text { danger for the life and cultural values of the nation that will } \\
\text { ultimately undermine national security. Researchers divide the } \\
\text { efforts of drug misuse prevention by the National Narcotics } \\
\text { Agency part of the preventive and repressive. Both of these are } \\
\text { key functions (operations) in accordance with the duties of the } \\
\text { National Narcotics Agency. The misuse of and illicit traffic in } \\
\text { narcotic drugs, psychotropic substances and other hazardous } \\
\text { materials (drugs) with various implications and the negative } \\
\text { impact is a global problem that threatens the life of the } \\
\text { community, state and nation. The National Narcotics agency } \\
\text { has mengakomidir theory such as that reflected from the } \\
\text { division of tasks fields are categorized into the Areas of } \\
\text { Prevention and Community Empowerment, Eradication, and } \\
\text { Rehabilitation. }\end{array}$ \\
\hline & Abstrak \\
\hline $\begin{array}{l}\text { Kata kunci: } \\
\text { Pemahaman Hukum; } \\
\text { Pembinaan Masyarakat; } \\
\text { Penyalahgunaan Narkoba. }\end{array}$ & $\begin{array}{l}\text { Penyalahgunaan narkotika merupakan bahaya yang sangat } \\
\text { memprihatinkan, karena narkotika dapat merusak pribadi-pribadi para } \\
\text { penggunanya, baik secara fisik maupun mental. Penyalahgunaan dan } \\
\text { peredaran narkotika secara illegal sangat merugikan perorangan } \\
\text { maupun masyarakat luas khususnya generasi muda, bahkan dapat } \\
\text { menimbulkan bahaya yang lebih besar bagi kehidupan dan nilai-nilai }\end{array}$ \\
\hline $\begin{array}{l}\text { Corresponding Author: } \\
\text { Sami'an, E-mail: } \\
\text { dosen.samian@gmail.com }\end{array}$ & $\begin{array}{l}\text { budaya bangsa yang pada akhirnya akan dapat melemahkan ketahanan } \\
\text { nasional. Peneliti membagi upaya penanggulangan penyalahgunaan } \\
\text { narkoba oleh Badan Narkotika Nasional bagian, yakni preventif, dan } \\
\text { represif. Kedua hal ini merupakan fungsi-fungsi utama (operasional) }\end{array}$ \\
\hline P-ISSN: 1412-6605 & $\begin{array}{l}\text { sesuai dengan tugas pokok Badan Narkotika Nasional. } \\
\text { Penyalahounaan dan peredaran gelap narkotika, psikotropika dan }\end{array}$ \\
\hline E-ISSN: $2301-6426$ & $\begin{array}{l}\text { bahan berbahaya lainnya (narkoba) dengan berbagai implikasi dan } \\
\text { dampak negatifnya merupakan suatu masalah global yang } \\
\text { mengancam kehidupan masyarakat, bangsa dan negara. Badan } \\
\text { Narkotika Nasional telah mengakomidir teori tersebut seperti yang } \\
\text { tercermin dari pembagian tugas bidang yang di kategorikan kedalam } \\
\text { Bidang Pencegahan dan Pemberdayaan Masyarakat, Pemberantasan, } \\
\text { dan Rehabilitasi. }\end{array}$ \\
\hline
\end{tabular}




\section{Introduction}

Circulation and misuse of dangerous, addictive substances are now more and more widespread among Indonesian people, especially teenagers. It is a fact that drugs are all around us. Drug users can damage the order of family life, the community, and the school environment, even directly or indirectly a threat to the continuity of development and the future of the Indonesian nation and state. Observing the development of drug distribution and use among teenagers is very worrying because drugs threaten the end of the nation's children.

Narcotics misuse is a worrying danger because narcotics can damage the users' personalities, both physically and mentally. The misuse and illegal distribution of narcotics are detrimental to individuals and the wider community, especially the younger generation. They can even pose a greater danger to the life and cultural values of the nation, which will ultimately weaken national resilience. Even transnational narcotics crimes are generally carried out using the modus operandi and modern technological means. Narcotics and psychotropics are drugs or materials useful in treatment, health services, and scientific development. On the other hand, it can cause dangerous dependence if used without strict and thorough supervision. ${ }^{1}$

Drug trafficking carried out with sophisticated techniques has penetrated throughout Indonesia. It can be said that there has been a change in the modus operandi of the syndicates, where particular types of psychotropics are no longer imported. Still, the dealers prefer to set up factories to produce their own. Procurement of raw materials, compounding, and recruitment of people related to the division of tasks in making drugs are well planned. This can be said when looking at the trend of cases of drug factories that have continued to emerge in the last few years, and even the innovation of narcotic products is increasingly diverse. This is done to deceive law enforcement officers. ${ }^{2}$

The development of narcotics crime has become a severe threat to the life of every nation and humanity in general. The increasing number of addicts will result in disturbances to public security and order, from increasing crime to other social diseases. In general, adolescents do not know the consequences of drug misuse. They only know that they will get a sense of pleasure by using narcotics by imagining only pleasant feelings. Narcotic substances were shown initially for medicinal purposes. Still, with the development of science and technology, so many drugs can be processed, and their functions can also be misused. ${ }^{3}$

Fans of frenzied crowds of night entertainment have become an easy target for dealers. In the name of satisfaction in enjoying entertainment, they often use

${ }^{1}$ Muhammad Yamin, Tindak Pidana Khusus, Cetakan Pertama (Bandung: Pustaka Setia, 2012).

2 Wulandari Berliani Putri and others, 'Medicolegal Perspective on Physician-Induced Demand Issue', Bestuur, 9.1 (2021), 77-89.

${ }^{3}$ Moh. Makaro Taufik, Suhasril, and Moh. Zakky, Tindak Pidana Narkotika, Cetakan Kedua (Bogor: Ghalia Indonesia, 2005). 
ecstasy and methamphetamine, a type of psychotropic that is already familiar. Thus, it is strongly suspected that nightclubs have become a hotbed for drug trafficking.

We already know that criminal sanctions for drug dealers in Indonesia are hefty. It can even be subject to the death penalty, as has been done by the Indonesian government today. The penalty for drug dealers in Indonesia is a minimum of 4 years and a maximum sentence of death. In addition to a consistent government that is always ready to carry out drug eradication, it would be excellent for young people to know the penalties that apply to drug dealers, as stated in Law Number 35 of 2009 concerning Narcotics. ${ }^{4}$

Most of the misusers are teenagers and highly educated, which is the nation's invaluable capital, is undoubtedly very concerning. The enormous economic and social impact of drug misuse reminds us that efforts to prevent and eradicate drugs are urgent because they can have a systemic effect. 5

As part of the government apparatus, the National Narcotics Agency (BNN) has the obligation and authority to prevent and eradicate drugs according to the applicable legislation. 6 Without the cooperation and participation of the community, the duties and authorities of the National Narcotics Agency will certainly not run optimally. ${ }^{7}$ Based on the above background, the researcher wants to provide a legal understanding of the dangers of drugs in the context of community development to prevent drug misuse.

\section{Methods}

In descriptive research, it can be defined as a research method that describes the characteristics of the population or phenomena that the writer is observing. This type is used because the researcher wants to get a clear picture and information regarding the legal understanding of the problem of the dangers of drugs in the context of community development to prevent drug misuse, the extent to which the performance of law enforcers, either by direct action (repressive) or prevention (preventive). Research is a scientific activity based on specific methods, systematics, and thoughts, which aims to study certain legal phenomena by analyzing them. An in-depth examination of the legal facts is also

\footnotetext{
${ }^{4}$ Hendry Julian Noor, Kardiansyah Afkar, and Henning Glaser, 'Application of Sanctions Against State Administrative Officials Failing to Implement Administrative Court Decisions', Bestuur, 9.1 (2021), 53-67.

${ }^{5}$ Utkarsh K. Mishra and Abhishek Negi, 'Should Trade Remedies Be Eliminated from WTO: A Response to Tania Voon', Journal of Human Rights, Culture and Legal System, 1.3 (2021).

${ }^{6}$ Badan Narkotika Nasional Republik Indonesia (BNN), Mahasiswa Dan Bahaya Narkoba (Jakarta, 2012).

7 Putri and others.
} 
held to seek a solution to the problem then. -problems that arise in the symptom concerned. ${ }^{8}$

\section{Results and Discussion}

\section{Preventive Action}

Preventive action is an action taken to prevent or maintain the possibility of

a crime occurring. According to A. Qirom Samsudin M, about taking preventative action, preventing crime is better than educating criminals to become good again because it is not only considered in terms of costs, but this effort is more straightforward. It will get satisfactory results or achieve goals. The National Narcotics Agency conducts prevention and empowerment about the drug problem, which is a better action than punishing or rehabilitating drug misusers. Preventive handling carried out by the National Narcotics Agency is related to the similarity of needs, reducing drug misuse in the community. This is done when the crime rate related to drug misuse is higher, so a separate operation is needed outside of the daily operations.

\section{Preventive Action}

Repressive actions are all actions taken by law enforcement officials after a criminal act. Repressive actions are more focused on people who commit criminal acts, namely, among others, by providing a law (criminal) that is commensurate with their actions. This action can also be seen as a precaution for the future. This action includes how law enforcement officers carry out investigations, follow-up investigations, criminal prosecutions, examinations in court, executions, and so on until the coaching of prisoners. This repressive handling of crime is also carried out with rehabilitation techniques. ${ }^{9}$

The repressive efforts began when the police received information about a crime. This information can come from public reports, mass media, directly known by the authorities, or data provided by police intelligence. After receiving the information, the Narcotics Unit did not immediately go to the field to enforce the law. However, officers in the area were ordered to find out the truth of the information. Thus, in the event of misinformation, the police will not waste too much time, funds, and human resources for nothing. The investigation technique to find out the truth of information can be done in various ways, namely observation, interviews, surveillance (following), and undercover (disguise). Based on the explanation of Moore and Trojanowics,

8 Soerjono Soekanto, Pengantar Penelitian Hukum (Jakarta: UI-Press, 2011).

9 I Dewa Made Suartha, 'Criminal Policy Formulation on Regulation of Death Penalties for

Criminal Actors', Journal of Morality and Legal Culture, $1.1 \quad$ (2020), 12 <https://doi.org/10.20961/jmail.v1i1.44743>. 
this operational strategy can be called proactive policing, where the police begin to take advantage of public information. ${ }^{10}$

After the information received was believed to be accurate, the Drugs Unit moved to make arrests. In the case of being caught red-handed, an investigation can also be carried out by confiscation of evidence. The arrest process, including searches and seizures carried out by the Narcotics Unit above, is legally based on a solid reason that a crime has occurred. The cause itself is the truth of the information that the police had previously received when the investigation was carried out. As with other police units, the Narcotics Unit also investigated the suspect after making the arrests. In this stage, the Narcotics Unit prepares reports, prepares Criminal Proceedings (BAP) for witnesses and suspects, and conducts an examination of evidence in the laboratory. ${ }^{11}$

The process of overcoming drug misuse carried out by the National Narcotics Agency still has obstacles. Some of these obstacles are acknowledged by the National Narcotics Agency that they have greatly hampered their performance in carrying out their general duties. Barriers that are usually experienced come from both inside and outside the Drug Unit.

\section{Prevention of Drug Misuse}

\section{a. Definition of Drugs}

Narcotics and illegal drugs (DRUGS) or Narcotics, Psychotropics, and Addictive Substances (Drugs) can affect a person's psychological condition, which can cause physical and mental dependence. According to Law Number 35 of 2009 concerning Narcotics, "Narcotics are substances or drugs derived from plants or non-plants, both synthetic and non-synthetic, which can cause decreased or altered consciousness and loss of taste. This substance can reduce or even eliminate pain and can cause dependence. Drug misuse \& addiction (Narcotics, alcohol \& addictive substances). Due to drugs, those who consume drugs will experience mental and behavioral disorders resulting from disruption of the neurotransmitter system in the cells of the central nervous system in the brain. ${ }^{12}$

The word narcotics comes from the Greek narcotics, which means lethargy in medical language, in a state of torpor, weakness, fatigue, and exhaustion. In general, the definition of narcotics is a substance that can

${ }^{10}$ Arif Purnama Oktora and Hilaire Tegnan, 'Strategy for Implementing Operations to Handle the Crime of Narcotics', Journal of Human Rights, Culture and Legal System, 1.3 (2021).

${ }^{11}$ Nurfaika Ishak, Rahmad Ramadhan Hasibuan, and Tri Suhendra Arbani, 'Bureaucratic and Political Collaboration Towards a Good Governance System', Bestuur, 8.1 (2020), 19 <https://doi.org/10.20961/bestuur.v8i1.42922>.

${ }^{12}$ Dadang Hawari, Penyalagunaan \& Ketergantungan NAZA, 2nd edn (Jakarta: Gaya baru, 2006). 
cause changes in feelings, reasoning, and observation, because these substances affect the central nervous system. ${ }^{13}$

The word narcotics comes from the English language, narcotics, which means drugs. In Greek, it is called narcosis, which means to put to sleep or anesthetize. The definition of narcotics is a substance or drug, whether derived from plants, synthetic, or semi-synthetic, which can cause a decrease or change in consciousness, loss of taste, reduce to eliminate pain, and cause dependence. In general, narcotics can reduce and change consciousness (analgesic). In the world of medicine, this compound is commonly used as an anesthetic (anesthetic) used to anesthetize people who are going to be operated on so they don't feel pain during the operation. In addition, narcotics are also used for cough suppressants (antitussives) and pain suppressants (analgesics). ${ }^{14}$

Narcotics are substances or drugs that are very useful and necessary for the treatment of certain diseases and the benefit of science. However, if it is misused or used not following treatment standards, it can have detrimental consequences for individuals or society, especially the younger generation. ${ }^{15}$ This will be more detrimental if accompanied by misuse and illicit trafficking of narcotics, resulting in more significant danger to the life and cultural values of the nation, which in turn will weaken national resilience. Narcotics or drugs are drugs, substances, and substances that, when taken, inhaled, inhaled, swallowed, or injected, affect the brain's functioning and often cause dependence, as a result of which the work of the brain changes (increases or increases decreases), likewise with the vital functions of other body organs, such as the heart, blood circulation, and respiration. ${ }^{16}$

Narcotics are substances or drugs derived from plants or non-plants, both synthetic and semi-synthetic, which can cause a decrease or change in consciousness, eliminate or reduce pain.

Psychotropics are substances or drugs, both natural and synthetic, which have psychoactive properties through being selective in the central nervous system and characteristic changes in mental and behavioral activities and causing dependence. Psychotropics are nonnarcotic substances or drugs, both naturally and synthetically, which have psychoactive properties through selective effects on the central

${ }^{13}$ Darmono, Toksikologi Narkoba Dan Alkohol (Pengaruh Neorotoksisitasnya Pada Saraf Otak) (Jakarta: UI-Press, 2006).

${ }^{14}$ Ida Listyarini Handoyo, Narkoba Perlukah Mengenalnya? (Yogyakarta: PT Pakar Raya, 2004).

${ }^{15}$ Devi Triasari, 'Right to Sanitation: Case Study of Indonesia', Journal of Human Rights, Culture and Legal System, 1.3 (2021).

${ }^{16}$ Lydia Harlina Martono and Satya Joewana, Pencegahan Dan Penanggulangan Penylahgunaan Narkoba Berbasis Sekolah (Jakarta: Balai Pustaka (Persero), 2006). 
nerves that can cause remarkable changes in everyday activities. Doctors commonly use these psychotropics to treat mental disorders (psyche) patients. Meanwhile, other addictive groups are substances other than drugs and psychotropic substances that can cause dependence, such as cigarettes, alcohol and intoxicating drinks, thinner, and other substances such as wood glue, liquid eraser, or acetone. Addiction is a condition in which the sufferer is dependent on repeated doses of the drug and will use ever-larger doses and even switch to more dangerous drugs. The three main characteristics of drug addiction are using large amounts of the drug. Unsuccessful use of the drug and symptoms regress. ${ }^{17}$

In Indonesia, Cannabis (Cannabis Sativa) is widely grown in Aceh and other areas of Sumatra. Residents have long used this type of marijuana as an ingredient for daily food. Meanwhile, Erythroxylon Coca (Cocaine) plants are widely grown and are found in the East Java area. Initially, cocaine was only intended for export.

Based on the acquisition, Narcotics can be divided into two types:

1) Natural narcotics; are plant parts taken from certain plants such as opium, morphine, heroin, marijuana, hashish, codeine, or cocaine.

2) Synthetic narcotics; is a narcotic resulting from a mixture of chemicals from a specific process, and their effects can be disguised with natural drugs.

In today's era, new types of synthetic drugs such as cathinone, blue sapphire, gorilla marijuana, ketamine, PCC pills, and so on continue to develop along with rapid technological advances. Therefore, it must be wary of drug misuse from this new type. ${ }^{18}$ Dadang Hawari defines narcotics substance misuser as consumption outside of medical indications, without a doctor's instructions/prescription, consumed regularly or periodically for at least one month. This consumption is pathological and causes impairment in social, work, and school functions. ${ }^{19}$

\section{b. Drugs Misuse}

Drug misuse is the use of drugs regularly that is not for medicinal purposes or is used without following the proper dosage rules.

17 Tho Lai Hong and Ho Peck Leng, Sains I (Diterjemahkan Oleh Purbodiningrat Dan Geino U. Purbodiningrat). (Jakarta: PT Aqua Mandiri, 2001).

18 Resti Dian Luthviati and Suviwat Jenvitchuwong, 'Implementation of Halal Product Assurance in the Pharmaceutical Sector in Indonesia', Journal of Human Rights, Culture and Legal System, 1.3 (2021).

${ }^{19}$ Suhendar, 'Persepsi Remaja Terhadap Penyalahgunaan Obat/ Zat Adiktif', Jurnal Ilmiah Pekerjaan Sosial, 3.1 (2004). 
Drug misuse is a process that is increasing from the level of trial to the level of use for entertainment, situational use, regular use, to dependence. Entering trial and error level can be directly dragged into the level of addiction because of the nature of drugs that can cause high reliance. Drug misuse can cause dropping out of school, work, destroying the future, violent traffic accidents, crimes, and useless death. If drug use is reduced or stopped suddenly, it will cause withdrawal symptoms (withdrawal syndrome), namely feelings of pain throughout the body unstoppable body. Once you try drugs, there is a risk of wanting to try and try again so that eventually addiction and dependence arise. ${ }^{20}$

The effect of dependence/addiction is a stage that the individual feels after using the drug repeatedly. However, the term dependence explicitly describes the existence of two kinds of dependence, namely physical dependence and psychological dependence. Physical dependence is the appearance of withdrawal symptoms/physical symptoms observed. Suppose the individual stops using the drug, while psychological dependence is the existence of a great desire or urge from the individual to continue using the medicine and feel negative feelings/discomfort if the use is discontinued. Drug users generally only want to stop when it is too late. They are already in a dependency that cannot be abandoned. ${ }^{21}$

\section{c. Socialization as Effective Communication}

Carrying out human communication in the surrounding environment, every human being must have their ways and rules, both written and unwritten rules. Every law that has been built in the order of community life will undoubtedly experience existence as long as there is a conformity of values in it. As for the addition of new agreements, of course, there will be a process of addition and adjustment in line with the needs of the people in it. The agreements that live in the community will bind every community element in it. This cannot be separated from the word socialization, where people exchange messages and values. As with the birth of an agreement in society, the socialization process occurs as a community understanding and appreciation of the events around them.

According to Onong Uchajana Effendy, socialization is the provision of knowledge resources that enable people to behave and act as

${ }^{20}$ Lego Karjoko and others, 'Patent Policy on The Pharmaceutical Sector in Indonesia', 23.5 (2020), 1-13 <https://www.abacademies.org/articles/patent-policy-on-the-pharmaceutical-sector-inindonesia-9670.html>.

${ }^{21}$ Mishra and Negi. 
influential members of society which causes awareness of their social functions to be active in the community. ${ }^{22}$

According to Soerjono Soekanto, socialization is a process of social interaction, namely the social basis, referring to dynamic social relationships. Social interaction occurs because each is aware of the other party's existence which causes changes, thus creating an impression in one's mind, determining what action will be taken.

Judging from its function, socialization is an essential element for the passage of organizational communication in society. The communication referred to here is an effective way of exchanging any values that are considered necessary. The point is how in the process of communication interaction in the community, messages by communicators can be conveyed effectively and affect the recipient of the message (the communicator). The expected results here in the communication process include cognitive effects (knowledge), impact on attitudes, and effects on behavior. With the message and content conveyed through the communication process, the recipient who previously did not have any knowledge becomes aware of and understands the statement. Thus, the expected results in conveying the message follow the objectives of effective communication. ${ }^{23}$

A criminal act is an act that is prohibited by the rule of law, which prohibition is accompanied by threats (sanctions) in the form of certain crimes for anyone who violates the ban. In this case, whoever breaks the prohibition and has been regulated in law, the perpetrators can be subject to sanctions or penalties, while the criminal threat is shown to the person who caused the incident.

The Narcotics Law emphasizes the role of the community to take an active part in the fight against narcotics crime. This includes the role of society, especially for teenagers. Article 104 of the Narcotics Law states: The community has the amplest opportunity to participate in helping the prevention and eradication of narcotics misuse.

Drug misuse and illicit traffickings are a government problem and a problem that must be tackled together. Prevention and eradication of drug misuse and illegal trafficking are carried out by building community-based prevention efforts.

22 Onong Uchana Efendy, Ilmu Komunikasi Teori Dan Praktek (Bandung: Remaja Rosda Karya, 2005).

${ }^{23}$ Oktora and Tegnan. 


\section{IV.Conclusion}

There are three efforts to overcome drug misuse that need to be done against drug misuse: conducting counseling, taking action, and rehabilitation. By conducting counseling or outreach to the community, such as conducting antidrug seminars and explaining the dangers of drugs and their impact on health if drugs are used continuouslyTo eradicate drugs, such as conducting raids at night entertainment or karaoke places to capture criminals. Drug users can take action as soon as possible so that drugs do not run rampant in the community. In the theory of crime prevention, wherein an effort to tackle crime, there are two ways: preventive (preventing before the occurrence of a crime); repressive action (business after the occurrence of a crime); and rehabilitation. To find out about the dangers of drugs through every activity organized by BNN, both socialization, dissemination, advocacy, and so on so that the community has selfimmunity or resistance to drugs to avoid drug misuse and illicit trafficking.

\section{Refrences}

Badan Narkotika Nasional Republik Indonesia (BNN), Mahasiswa Dan Bahaya Narkoba (Jakarta, 2012)

Darmono, Toksikologi Narkoba Dan Alkohol (Pengaruh Neorotoksisitasnya Pada Saraf Otak) (Jakarta: UI-Press, 2006)

Efendy, Onong Uchana, Ilmu Komunikasi Teori Dan Praktek (Bandung: Remaja Rosda Karya, 2005)

Handoyo, Ida Listyarini, Narkoba Perlukah Mengenalnya? (Yogyakarta: PT Pakar Raya, 2004)

Hawari, Dadang, Penyalagunaan \& Ketergantungan NAZA, 2nd edn (Jakarta: Gaya baru, 2006)

Hong, Tho Lai, and Ho Peck Leng, Sains I (Diterjemahkan Oleh Purbodiningrat Dan Geino U. Purbodiningrat). (Jakarta: PT Aqua Mandiri, 2001)

Ishak, Nurfaika, Rahmad Ramadhan Hasibuan, and Tri Suhendra Arbani, ‘Bureaucratic and Political Collaboration Towards a Good Governance System', Bestuur, 8.1

(2020), <https://doi.org/10.20961/bestuur.v8i1.42922>

Karjoko, Lego, Said Gunawan, A L Sentot Sudarwanto, Heriyanti, Zaidah Nur Rosidah, I Gusti Ayu Ketut Handayani, and others, 'Patent Policy on The Pharmaceutical Sector in Indonesia', 23.5 (2020), 1-13 $<$ https://www.abacademies.org/articles/patent-policy-on-thepharmaceutical-sector-in-indonesia-9670.html>

Luthviati, Resti Dian, and Suviwat Jenvitchuwong, 'Implementation of Halal Product Assurance in the Pharmaceutical Sector in Indonesia', Journal of Human Rights, Culture and Legal System, 1.3 (2021) 
Martono, Lydia Harlina, and Satya Joewana, Pencegahan Dan Penanggulangan Penylahgunaan Narkoba Berbasis Sekolah (Jakarta: Balai Pustaka (Persero), 2006)

Mishra, Utkarsh K., and Abhishek Negi, 'Should Trade Remedies Be Eliminated from WTO: A Response to Tania Voon', Journal of Human Rights, Culture and Legal System, 1.3 (2021)

Noor, Hendry Julian, Kardiansyah Afkar, and Henning Glaser, 'Application of Sanctions Against State Administrative Officials Failing to Implement Administrative Court Decisions', Bestuur, 9.1 (2021), 53-67

Oktora, Arif Purnama, and Hilaire Tegnan, 'Strategy for Implementing Operations to Handle the Crime of Narcotics', Journal of Human Rights, Culture and Legal System, 1.3 (2021)

Putri, Wulandari Berliani, Widyasari Vita, Juliet Musabula, and Muhammad Jihadul Hayat, 'Medicolegal Perspective on Physician-Induced Demand Issue', Bestuur, 9.1 (2021), 77-89

Soekanto, Soerjono, Pengantar Penelitian Hukum (Jakarta: UI-Press, 2011)

Suartha, I Dewa Made, 'Criminal Policy Formulation on Regulation of Death Penalties for Criminal Actors', Journal of Morality and Legal Culture, 1.1 (2020), 12 <https:/ / doi.org/10.20961/jmail.v1i1.44743>

Suhendar, 'Persepsi Remaja Terhadap Penyalahgunaan Obat/ Zat Adiktif', Jurnal Ilmiah Pekerjaan Sosial, 3.1 (2004)

Taufik, Moh. Makaro, Suhasril, and Moh. Zakky, Tindak Pidana Narkotika, Cetakan Kedua (Bogor: Ghalia Indonesia, 2005)

Triasari, Devi, 'Right to Sanitation: Case Study of Indonesia', Journal of Human Rights, Culture and Legal System, 1.3 (2021)

Yamin, Muhammad, Tindak Pidana Khusus, Cetakan Pertama (Bandung: Pustaka Setia, 2012) 